\title{
Efficacy of L1 Protein Vaccines Against Cervical and Vaginal Cancer: A Systematic Review and Meta-Analysis
}

\author{
Tahoora Mousavi, ${ }^{1}$ Mahmood Moosazadeh, ${ }^{2}$ Mahdi Afshari, ${ }^{3}$ Lotfollah Davoodi, ${ }^{4}$ and Mohammadreza \\ Haghshenas ${ }^{5, *}$ \\ ${ }^{1}$ PhD Student in Molecular and Cell Biology, Student Research Committee, Molecular and Cell Biology Research Center, Faculty of Medicine, Mazandaran University of \\ Medical Sciences, Sari, IR Iran \\ ${ }^{2}$ Health Sciences Research Center, Faculty of Health, Mazandaran University of Medical Sciences, Sari, IR Iran \\ ${ }^{3}$ Department of Community Medicine, Zabol University of Medical Sciences, Zabol, IR Iran \\ ${ }^{4}$ Infectious Disease Specialists, Antimicrobial Resistance Research Center, Mazandaran University of Medical Sciences, Sari, Iran \\ ${ }^{5}$ Department of Microbiology, Molecular and Cell-Biology Research Center, Faculty of Medicine, Mazandaran University of Medical Sciences, Sari, IR Iran \\ "Corresponding author: Mohammadreza Haghshenas, Department of Microbiology, Molecular and Cell-Biology Research Center, Faculty of Medicine, Mazandaran University \\ of Medical Sciences, Sari, IR Iran. E-mail: haghshenas2001@yahoo.com
}

Received 2016 October 02; Revised 2016 November 20; Accepted 2016 December 06.

\begin{abstract}
Context: Cervical and genital infections are responsible for the more common sexually transmitted cancers among women aged 14 - 55 years. There are more than 100 HPV types which cause 60\% - 70\% (high risk types: 16,18) and 90\% (low risk types: 6, 11) cervical cancers. This study aimed to evaluate the efficacy of L1 protein vaccines against cervical and vaginal cancer.

Evidence Acquisition: Different databases (including Scopus, Google scholar, PubMed, Cochrane, and Science Direct) were searched using relevant keywords such as Gardasil, Cervarix, and cervical cancer. After restricting the search strategy and excluding duplicates, the remained articles were screened by investigating their titles, abstracts, and full texts. Cochrane Q-test and I-squared index were used to detect the heterogeneity among the results, and fixed effect model was applied to estimate the pooled risk ratio. Results: By combining the results of 10 primary articles, the efficacy of monovalent (HPV16), bivalent (HPV 16, 18), and quadrivalent (HPV16,11,6,8) vaccines was estimated between $86 \%$ and $100 \%$.

Conclusions: The results of this meta-analysis showed that Gardasil and Cervarix vaccines are highly effective against cervical cancer. According to the point that approximately 50\% of cervical cancers and human carcinogenicity are related to HPV-16 infection, the bivalent HPV vaccine might have protective effects against HPV-16 CIN2-3 lesion and cervical cancer.
\end{abstract}

Keywords: Gardasil, Cervarix, L1 Protein, Human Papilloma Virus, Vaccine

\section{Introduction}

Cervical and genital infections are responsible for the more common sexually transmitted cancers among women aged 14 - 55 (1). It is estimated that 530,000 people are infected and 275,000 die annually due to cervical can$\operatorname{cer}(2,3)$.

More than 100 HPV types have been identified, and high-risk types $(16,18)$ are responsible for approximately $60 \%-70 \%$ of all cervical cancers. It also contains low-risk types $(6,11)$ which are responsible for $90 \%$ of genital warts worldwide (4-10). Some of the HPV types are associated with cutaneous warts, and some of them are detected in the skin lesions (10). The other types are related to malignant lesions such as external genital warts, intraepithelial neoplasia of penis (PIN), anus (AIN), vulva (VIN), vagina (VAIN), cervix (CIN) and also cervical cancer (11-14). Two prophylactic vaccines, Gardasil and Cervarix, are available since 2006 with approximately 100\% efficacy to prevent mortalities (15). A bivalent vaccine (Cervarix) targets two types of HPV (16,18), while quadrivalent vaccine (Gardasil) acts against these types as well as two other HPV types $(6,11)$ that cause cutaneous genital warts $(16,17)$. The evidence shows that there is a relationship between persistent HPV infection and development of cervical intraepithelial neoplasia (CIN) and cervical cancer (18-21). Thus, vaccination with quadrivalent HPV vaccine among naive women not exposed to HPV16/18 can prevent CIN1, CIN2, and CIN3 grades of cancer related to HPV16/18 among females aged 16 - $26(22,23)$.

HPV16 is the most oncogenic type associated with approximately half of all cervical cancers worldwide. Prophylactic HPV16 vaccines as a highly effective tool can be used to prevent cervical cancer. Persistent HPV infections are necessary for cervical lesions CIN 2- 3. Some studies show that prophylactic HPV16 L1 virus-like particle (VLP) vaccination inhibited persistent HPV16 infections when followed averagely for 1.5 years $(24,25)$.

The purpose of this study was to evaluate the efficacy

Copyright (c) 2016, Iranian Red Crescent Medical Journal. This is an open-access article distributed under the terms of the Creative Commons Attribution-NonCommercial 4.0 International License (http://creativecommons.org/licenses/by-nc/4.0/) which permits copy and redistribute the material just in noncommercial usages, provided the original work is properly cited. 
of L1 protein vaccines against cervical and vaginal cancer.

\section{Data Source and Search Strategy}

In this study that was conducted in October 2016 in Mazandaran University of Medical Sciences, all relevant English-written literatures from 1990 to 2015 were investigated. The electronic medical databases used for the search were PubMed, Google scholar, Scopus, Science Direct, and Cochrane. In these databases, we used the key words corresponding MeSH term including "Papillomavirus", "Gardasil”, "Cervarix”, "Randomized”, "Randomised", "Controlled", and "Trial” by applying the following strategy: (Papillomavirus OR HPV) AND Vaccine AND (randomized or controlled or randomised) AND trial. We only selected randomized clinical trials (RCTs) about HPV vaccines (Gardasil, Cervarix) efficacy in preventing cervical and vaginal infections among women.

\section{Study Draft}

In this Meta analysis, all full texts and abstracts were collected via accurate and advanced searches. 1) Duplicate articles were removed; 2) studies were considered and irrelevant articles were excluded; 3 ) the results of the selected studies were analyzed to omit repeated articles.

\section{Inclusion Criteria}

In this study, all clinical trials investigating the efficacy of the L1 protein vaccines against cervical and vaginal cancer among healthy seronegative HPV DNA with a history of three doses vaccination were selected for meta-analysis. All achieved articles required to have quality scores.

Exclusion criteria: 1) studies that did not report specific sample size, 2) abstracts and studies presented in congresses without full texts, 3 ) non-RCTs and studies that did not achieve enough quality scores, 4) and duplicated studies were excluded from this study.

\section{Data Extraction}

Two different researchers independently evaluated all of the studies derived from the above databases and restricted them to per-protocol groups; then compared their results. In this study, the required data such as authors' names, publication year, country of origin, sample size of intervention and control groups, HPV types, type of protein used, and the effect estimates with corresponding 95\% confidence intervals (CIs) were extracted from all documents.

\section{Quality Assessment}

The quality of selected studies was evaluated by two reviewers (T.M, MM) using Jadad Score. This checklist consists of a 5-point scale to assess different aspects of methodology and quality of randomized trials. Studies with a total score of 3 or more were considered as qualified $(26,27)$. The final decision was made by a third reviewer.

Statistical analysis: All data analyses were performed by Stata V.11 software (StataCorp, College Station, TX, USA). A contingency table was designed for each clinical trial containing intervention/placebo groups' information. Weighting and combining the primary results were performed using inverse variance method. Cochrane $(\mathrm{Q})$ test and I squared indicators were applied to detect the degree of heterogeneity among the results. Since this heterogeneity was not statistically significant, we used fixed model for combining the results. Total estimate of relative risk (95\% confidence interval) for HPV infection prevalence was illustrated in forest plots (the size of each box indicated the study weight and crossed lines indicated 95\% confidence intervals). Using Egger test at the significance level of 0.1, the probable publication bias was evaluated. In some of the primary studies, no outcome had been observed in the intervention groups; then, we had to add 0.5 to each cell in the contingency tables to estimate continuity correction.

\section{Results}

During the first stage of our search, we identified 10444 papers indexed in PubMed (168), Google Scholar (7820), and Science Direct (2456). We could not access the other databases due to the limited accessibility in Iran. Of them, 7069 articles were excluded after setting some limitations in search strategy. Moreover, 2793 duplicated and 512 irrelevant papers were removed. Screening by full text review and quality assessment omitted another 60 papers. Finally, 10 articles having all inclusion criteria were considered for final meta-analysis. All these studies had been conducted to evaluate the vaccine efficacy against some genotypes (HPV 6 in four studies, HPV11 in four studies, HPV16 in 10 studies, and HPV8 in seven studies) (Figure 1).

Results of the primary studies showed that Gardasil and Cervarix vaccines have considerable efficacy for prevention of cervical and vaginal cancers among women, so that the efficacy of quadrivalent vaccine against HPV6 infection was reported from $73.1 \%$ to $100 \%$. Also, the efficacy of this vaccine against HPV11 was reported as 100\%. According to these results, the efficacy of monovalent (HPV16), bivalent (HPV 16, 18) and quadrivalent (HPV16,11,6,8) vaccines has been reported between $86 \%$ and $100 \%$. 


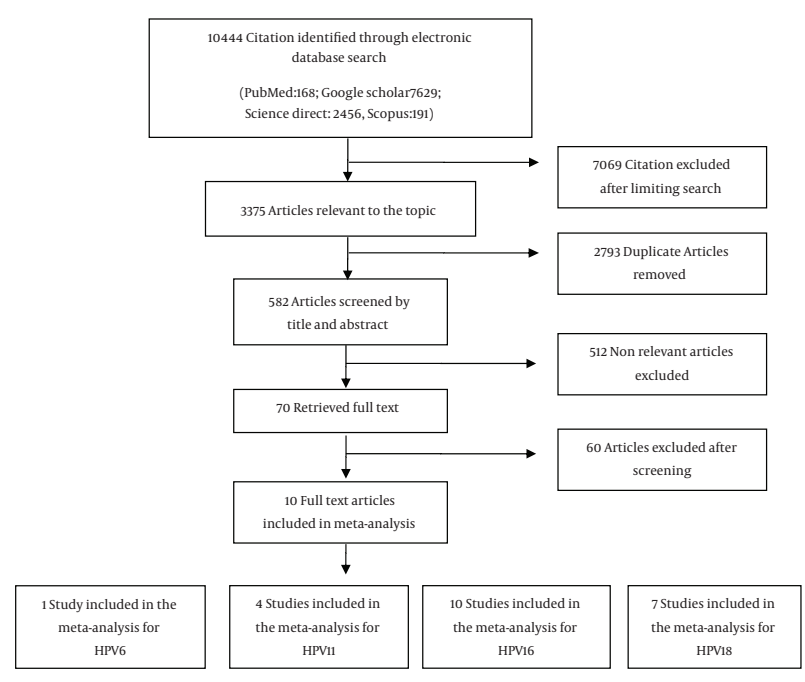

Figure 1. Flowchart of Selection of Studies for Inclusion in Meta-Analysis

Based on the heterogeneity indices for HPV16 vaccine (Isquared $=0, Q=10.6, P=0.6$ ), there was a low heterogeneity among the results. Therefore, we applied fixed effects model to combine the point estimates. The total relative risk for HPV16 vaccine to reduce cervical cancer risk was estimated as 0.06 (95\% CI: 0.04 - 0.09). Therefore, the total efficacy of this vaccine was $94 \%$ (91-96) (Figure 2). Moreover, the Egger test results showed no evidence of publication bias $(\beta=-1.1, \mathrm{P}=0.062)$.

Based on the heterogeneity indices for HPV11 vaccine (I-Squared $=0 \%, \mathrm{Q}=1.1, \mathrm{P}$ value $=0.894)$ and the low observed heterogeneity, the total relative risk for cancer development by this vaccine using fixed effects model was estimated as $0.19(95 \% \mathrm{CI}: 0.05-0.7)$. This means that the efficacy of vaccine against cervical cancer was $81 \%$ (30 - 95) (Figure 3). However, Egger test showed a significant publication bias $(\beta=4.3, \mathrm{P}=0.01)$.

Due to the low heterogeneity indices for HPV18 vaccine efficacy $(\mathrm{I}-$-Squared $=0 \%, \mathrm{Q}=1.8$, P value $=0.987$ ), fixed effects model estimated the pooled RR for HPV infection as 0.13 (95\% CI: 0.07-0.26). Therefore, as illustrated in Figure 4, the HPV18 vaccine efficacy against cervical cancer was 87\% (7493). No publication bias was observed ( $\beta=-0.3, \mathrm{P}=0.541)$.

In contrast to the other vaccines, we observed a great heterogeneity between the results of primary studies regarding HPV6 vaccine $(\mathrm{I}-S q u a r e d=75.6 \%, \mathrm{Q}=16.4$, $\mathrm{P}$ value $=$ 0.002). Therefore, random effects model was applied that estimated the pooled RR for this vaccine as 0.02 (95\% CI: 0.002 - 0.18). Thus, the HPV6 vaccine efficacy against cervical cancer was estimated as 98\% (81.8 - 99.8) (Figure 5). No evidence of publication bias was observed using Egger test $(\beta=-5.4, \mathrm{P}=0.114)$.

\section{Discussion}

The results of this study show that Prophylactic bivalent human papillomavirus (types 16, 18) and quadrivalent human papillomavirus (types 16, 18, 6, 11) vaccines are highly effective (100\%) in preventing persistent HPV infection. This study emphasizes that the HPV type 16 (HPV16) L1 virus-like particle vaccines are not only effective against persistent HPV16 infection, but also protect against HPV16-related CIN2-3 and cervical cancer. it is estimated that approximately $50 \%$ of cervical cancers and human carcinogenicity are related to HPV-16 infection (2830 ), thus, vaccination of young women with HPV-16 L1 provides strong protection and decreased HPV-16 infections associated with cervical intraepithelial neoplasia (CIN) 2/3 - Some studies confirmed that HPV-16 VLP vaccines are highly protective against multiple HPV types and reduce the incidence of cervical cancer. Women who have been vaccinated with one HPV type may protect against other HPV types (28).

Papillomavirus-like particle (L1 VLPs)-based subunit vaccines generate high serum titers of neutralizing antibodies that are primarily type-specific and provide near complete protection and limited cross-reactivity with other highly phylogenetically-related types associated with cervical cancer (31-33). L1 VLP vaccination even without an adjuvant induces high protection (34-37). In contrast to L1 VLP, the minor capsid protein (L2 VLPs) induces neutralizing antibodies and protects animals from papillomavirus; however, it is weakly immunogenic compared to L1 VLP and the duration of immunosuppression is not clear (38-40). 


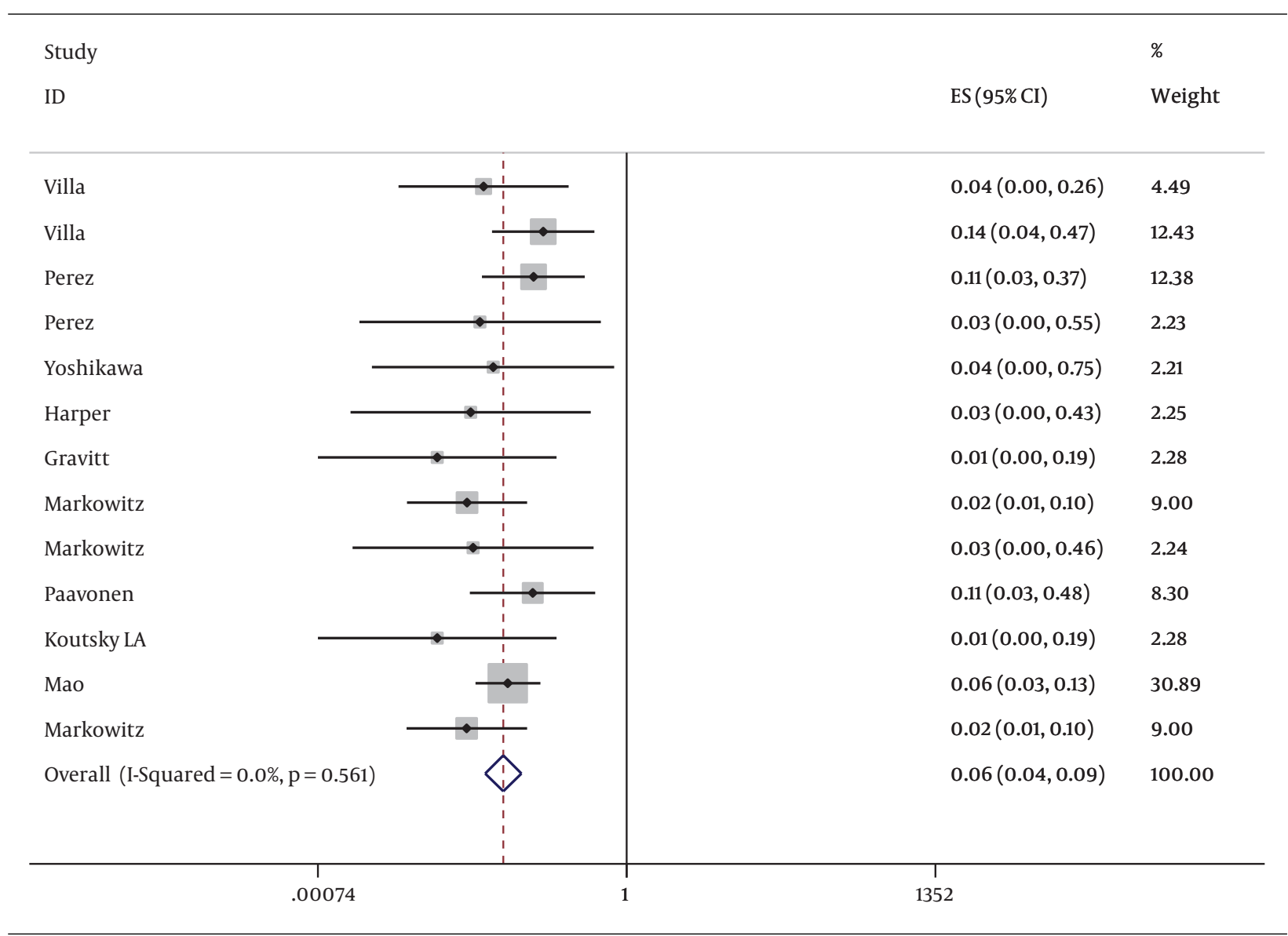

Figure 2. Forest Plot of the Pooled RR for HPV16 Vaccination Against HPV Infection

Gardasil and Cervarix are effective vaccines against different types of HPV infection $(6,11,16,18)$. These are classified as high-risk types for developing cervical cancer and genital warts. The results of a meta-analysis showed that prevalence of HPV16 and HPV18 among patients with cervical cancer was $44.8 \%$ and $14 \%$, respectively (41). Moreover, in a study conducted in Japan, $67.1 \%$ cases with cervical cancer were attributed to HPV type 16 and HPV type 18 (42). Frequencies of these genotypes among patients in North America and Europe were reported as $76.4 \%$ and $73.8 \%$, respectively (41).

Studies conducted among vaccinated and HPV negative women showed that prevalence of $\operatorname{HPV}(6,11,16,18)$ among women who received at least one dose of the vaccine decreased to $89 \%$ during 35 months, indicating the protective effect of vaccination. Quadrivalent vaccine could produce a strong immune response after seven months in vaccinated subjects. In addition, after 36 months, more than $94 \%$ of them showed high antibody titration against $\operatorname{HPV}(6,11,16)$ while $76 \%$ had serologic response against HPV18 (43). Another study carried out among 552 women vaccinated between ages 16 - 23 reported that quadrivalent vaccine can lead to the increased immune memory. It was also shown that seven days and 30 days after three vaccination doses, HPV antibody considerably increased, so that the antibody titration was more in these women than women at the beginning of vaccination (44). Villa et al. found that the efficacy of HPV vaccination increased from $89 \%$ to $95 \%$ within three years $(43,45)$.

In order to prevent vaginal HPV infection, HPV vaccination should be performed before the first sexual contact among young women. Studies conducted during a 24-month period showed that prevalence of HPV infection among women without history of sexual contact was $15.3 \%$ (46). Therefore, it seems that the risk of HPV infection is high during sexual contact that necessitates vaccination in this period. Cervarix with adjuvant ASO4 is a strong protector against HPV16 and HPV18 during 4 - 5 years. In addition, Gardacil with aluminum as adjuvant showed a good protection during five years especially against HPV16 (47). Some studies revealed that vaccination among girls aged 10 - 15 can develop higher immune response than vaccina- 


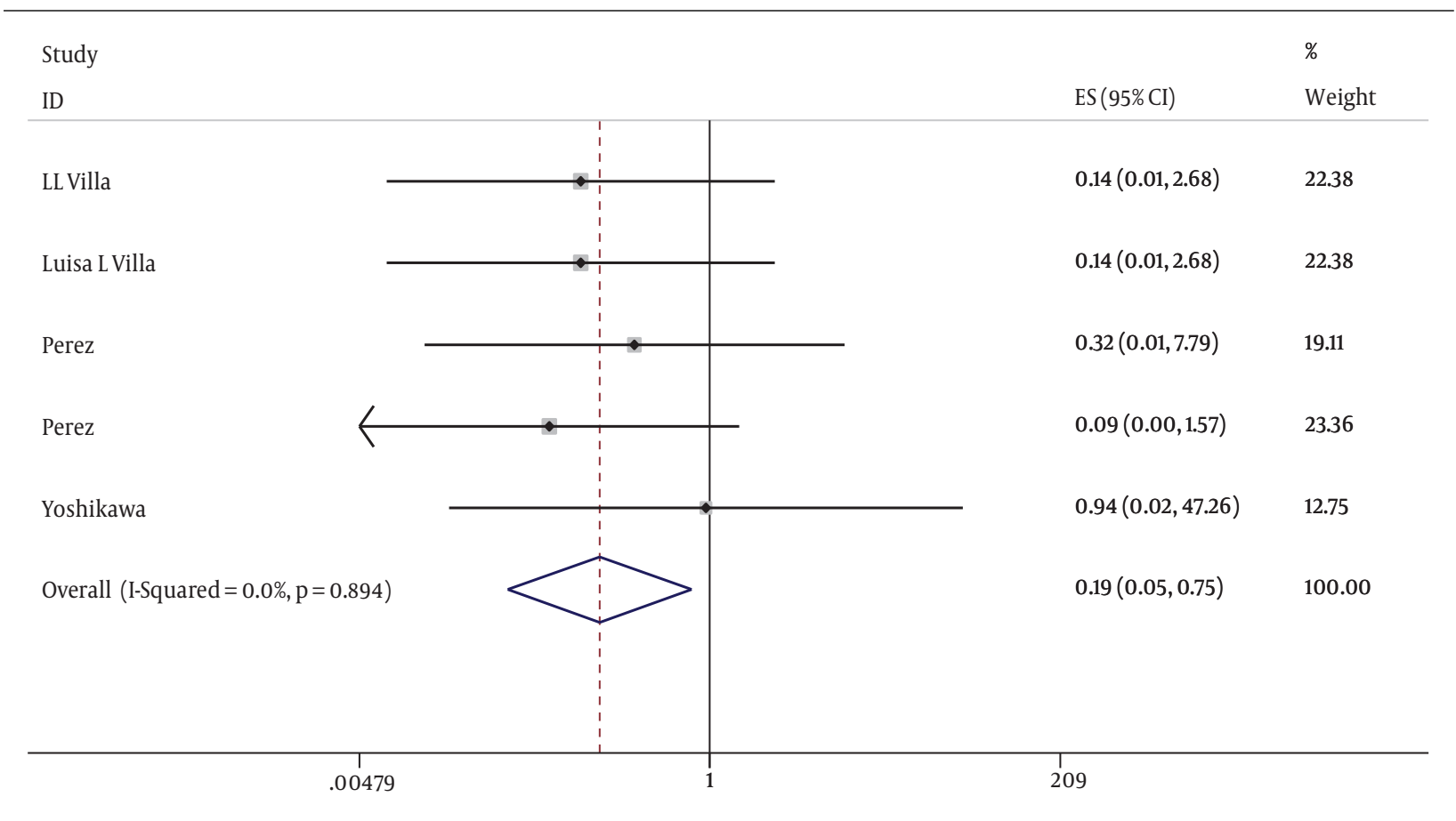

Figure 3. Forest Plot of the Pooled RR for HPV11 Vaccination Against HPV Infection

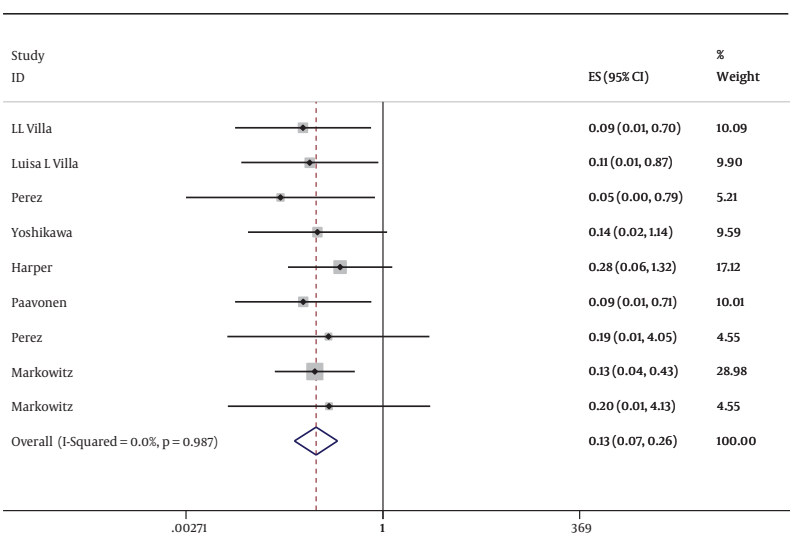

Figure 4. Forest Plot of the Pooled RR for HPV18 Vaccination Against HPV Infection

tion among 16 - 23 year-old women. Therefore, vaccination before sexual contact can develop long-term efficacy. Moreover, vaccination among multi-partner women can play an important role in the prevention of HPV infection (48).

Results of a study showed that deletion of human papillomavirus types 6 and 11 within vaccine can prevent developing genital warts and CIN staging and reduce costs and psychological problems associated with this disease (49). In developed countries without cancer screening programs, HPV vaccination is very crucial in reducing cervical cancer. Such effect depends on the vaccine efficacy, age,

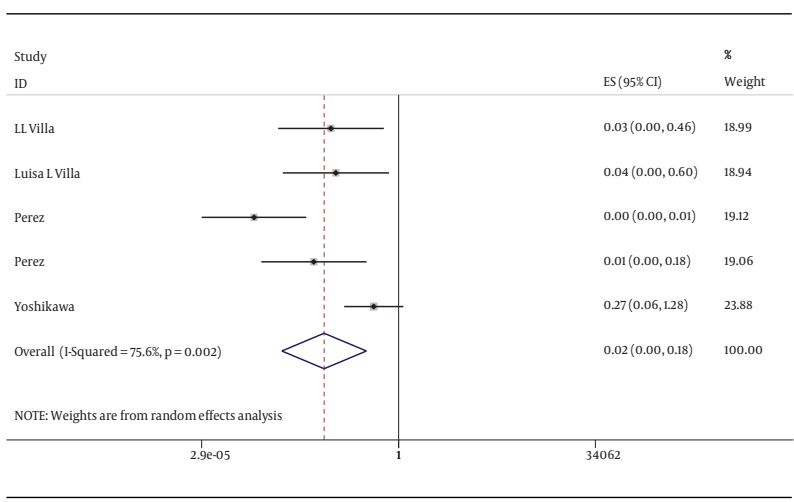

Figure 5. Forest Plot of the Pooled RR for HPV6 Vaccination Against HPV Infection

and protection period. Moreover, this vaccination can be more effective among 10 - 13 year-old HPV negative girls (5052).

This study showed that quadrivalent vaccine against $\operatorname{HPV}(6,11,16,18)$ can prevent developing infection as well as relevant diseases. There were some limitations in several primary studies such as small sample sizes and long follow-up periods. Therefore, our results might be prone to bias (Table 1). 
Table 1. Characteristics of Primary Studies According to HPV Types, Vaccine Type, and Efficacy

\begin{tabular}{|c|c|c|c|c|c|c|c|c|c|c|c|}
\hline \multirow[t]{2}{*}{ Type of HPV } & \multirow[t]{2}{*}{ Id } & \multirow[t]{2}{*}{ First Author } & \multirow{2}{*}{$\begin{array}{c}\text { Publication } \\
\text { Year }\end{array}$} & \multirow{2}{*}{$\begin{array}{c}\text { Country of } \\
\text { Origin }\end{array}$} & \multicolumn{2}{|c|}{ Intervention Group } & \multicolumn{2}{|c|}{ Control Group } & \multirow[t]{2}{*}{ Protein Used } & \multirow{2}{*}{$\begin{array}{l}\text { Capacity of } \\
\text { Vaccine }\end{array}$} & \multirow{2}{*}{$\begin{array}{l}\text { Percent of } \\
\text { Efficacy ( } 95 \% \\
\text { CI) }\end{array}$} \\
\hline & & & & & No. Outcome & No. Healthy & No. Outcome & No. Healthy & & & \\
\hline \multirow{5}{*}{ HPV6 } & 1 & Villa et al. (45) & 2006 & $\begin{array}{c}\text { USA, Brazil } \\
\text { Finland, Swe- } \\
\text { den,Norway }\end{array}$ & 0 & 214 & 17 & 209 & $6 / 11 / 16 / 18$ & 4 & $100(75.7,100.0)$ \\
\hline & 2 & Villa et al. (45) & 2006 & USA & 0 & 214 & 13 & 209 & $16 / 18 / 6 / 11$ & 4 & $(44.5,100.0)$ \\
\hline & 3 & Villa et al. (45) & 2006 & Brazil & 0 & 2077 & 8 & 1976 & $16 / 18 / 6 / 11$ & 4 & $100(68-100)$ \\
\hline & 4 & Villa et al. (45) & 2006 & Brazil & 0 & 2088 & 42 & 1990 & $16 / 18 / 6 / 11$ & 4 & $(91.3,100.0)$ \\
\hline & 5 & Villa et al. (45) & 2006 & Japan & 2 & 400 & 7 & 376 & $16 / 18 / 6 / 11$ & 4 & $73.1(41.1-97.3)$ \\
\hline \multirow{5}{*}{ HPV11 } & 1 & Villa et al. (45) & 2006 & $\begin{array}{l}\text { USA, Brazil } \\
\text { Finland, Swe- } \\
\text { den,Norway }\end{array}$ & 0 & 214 & 3 & 209 & $6 / 11 / 16 / 18$ & 4 & $100(0.0,100.0)$ \\
\hline & 2 & Villa et al. (43) & 2005 & USA & 0 & 214 & 3 & 209 & $16 / 18 / 6 / 11$ & 4 & $\mathrm{NA}$ \\
\hline & 3 & Perez et al. (53) & 2007 & Brazil & 0 & 2075 & 1 & 1976 & $16 / 18 / 6 / 11$ & 4 & $(<0.0,100.0)$ \\
\hline & 4 & Perez et al. (53) & 2007 & Brazil & 0 & 2088 & 5 & 1990 & $16 / 18 / 6 / 11$ & 4 & $(<0.0,100.0)$ \\
\hline & 5 & $\begin{array}{c}\text { Yoshikawa et al. } \\
(54)\end{array}$ & 2013 & Japan & 0 & 400 & 0 & 376 & $16 / 18 / 6 / 11$ & 4 & NA \\
\hline \multirow{13}{*}{ HPV16 } & 1 & Villa et al. (45) & 2006 & $\begin{array}{l}\text { USA, Brazil, } \\
\text { Finland, Swe- } \\
\text { den,Norway }\end{array}$ & 1 & 199 & 28 & 198 & $6 / 11 / 16 / 18$ & 4 & $96.6(79.2,99.9)$ \\
\hline & 2 & Villa et al. (43) & 2005 & USA & 3 & 199 & 21 & 198 & $16 / 18 / 6 / 11$ & 4 & $86(54-97)$ \\
\hline & 3 & Perez et al. (53) & 2007 & Brazil & 3 & 1990 & 25 & 1880 & $16 / 18 / 6 / 11$ & 4 & $(62.9,97.8)$ \\
\hline & 4 & Perez et al. (53) & 2007 & Brazil & 0 & 1993 & 14 & 1885 & 16/18/6/11 & 4 & $(71.4,100.0)$ \\
\hline & 5 & $\begin{array}{c}\text { Yoshikawa et al. } \\
(54)\end{array}$ & 2013 & Japan & 0 & 371 & 11 & 378 & $16 / 18 / 6 / 11$ & 4 & $\begin{array}{c}100.0(59.7- \\
100.0)\end{array}$ \\
\hline & 6 & $\begin{array}{l}\text { Harper et al. } \\
\text { (55) }\end{array}$ & 2004 & England & 0 & 366 & 18 & 355 & $16 / 11$ & 2 & $\begin{array}{c}100(79.4- \\
100.0)\end{array}$ \\
\hline & 7 & $\begin{array}{l}\text { Gravitt and } \\
\text { Shah (56) }\end{array}$ & 2005 & USA & 0 & 768 & 41 & 765 & $16 / 18 / 6 / 11$ & 4 & 100 \\
\hline & 8 & Markowitz (57) & 2014 & US & 2 & 6296 & 81 & 6160 & $16 / 18$ & 2 & $97.6(91.0-99.7)$ \\
\hline & 9 & $\begin{array}{l}\text { Markowitz et } \\
\text { al. (57) }\end{array}$ & 2014 & US & 0 & 6654 & 17 & 6467 & $16 / 18 / 6 / 11$ & 4 & $\begin{array}{c}100(76.5- \\
100.0)\end{array}$ \\
\hline & 10 & $\begin{array}{l}\text { Paavonen et al. } \\
\text { (58) }\end{array}$ & 2007 & Finland & 2 & 6701 & 18 & 6717 & $16 / 18$ & 2 & $\begin{array}{c}88.9(44.6- \\
99.2)\end{array}$ \\
\hline & 11 & $\begin{array}{l}\text { Koutsky et al. } \\
\text { (59) }\end{array}$ & 2002 & Africa & 0 & 768 & 41 & 765 & 16 & 1 & $100(90-100)$ \\
\hline & 12 & Mao et al. (28) & 2006 & California & 7 & 755 & 111 & 750 & 16 & 1 & $94(88-98)$ \\
\hline & 13 & $\begin{array}{l}\text { Markowitz et } \\
\text { al. (57) }\end{array}$ & 2014 & us & 2 & 6647 & 81 & 6455 & $16 / 18 / 6 / 11$ & 4 & $97.6(91.1-99.7)$ \\
\hline \multirow{9}{*}{ HPV18 } & 1 & Villa et al. (45) & 2006 & $\begin{array}{l}\text { USA, Brazil, } \\
\text { Finland, } \\
\text { Sweden, } \\
\text { Norway }\end{array}$ & 1 & 224 & 11 & 224 & 6/11/16/18 & 4 & $96.6(35.6,99.8)$ \\
\hline & 2 & Villa et al. (43) & 2005 & USA & 1 & 224 & 9 & 224 & $6 / 11 / 16 / 18$ & 4 & $89(21-100)$ \\
\hline & 3 & Perez et al. (53) & 2007 & Brazil & 0 & 2265 & 10 & 2201 & 6/11/16/18 & 4 & $(56.9,100.0)$ \\
\hline & 4 & $\begin{array}{l}\text { Yoshikawa et al. } \\
\text { (54) }\end{array}$ & 2013 & Japan & 1 & 403 & 7 & 396 & 6/11/16/18 & 4 & $86.0(8.9-99.7)$ \\
\hline & 5 & $\begin{array}{l}\text { Harper et al. } \\
\text { (55) }\end{array}$ & 2004 & England & 2 & 366 & 7 & 355 & $16 / 18$ & 2 & $72.3(32.5-93.4)$ \\
\hline & 6 & $\begin{array}{l}\text { Paavonen et al. } \\
\text { (58) }\end{array}$ & 2007 & Finland & 1 & 7221 & 11 & 7258 & $16 / 18$ & 2 & $90.9(22.1-99.9)$ \\
\hline & 7 & Perez et al. (53) & 2007 & Brazil & 0 & 2278 & 2 & 2215 & $6 / 11 / 16 / 18$ & 4 & $(<0.0,100.0)$ \\
\hline & 8 & $\begin{array}{l}\text { Markowitz et } \\
\text { al. (57) }\end{array}$ & 2014 & US & 3 & 6789 & 23 & 6739 & $16 / 18$ & 2 & $87.1(57.2-97.5)$ \\
\hline & 9 & $\begin{array}{l}\text { Markowitz et } \\
\text { al.(57) }\end{array}$ & 2014 & US & 0 & 7414 & 2 & 7343 & $6 / 11 / 16 / 18$ & 4 & $\begin{array}{c}100(<0- \\
100.0)\end{array}$ \\
\hline
\end{tabular}

\section{Conclusion}

In conclusion, since the efficacy of HPV vaccines against dysplasia is independent from race or geographi- cal area and considering the increasing prevalence of cervical cancer in different communities, it seems that vaccination before sexual contact can play a significant role in 
prevention of the disease. Although screening programs can be helpful in disease control, it cannot be an alternative for vaccination.

\section{Footnote}

Conflict of Interest: There is no conflict of interest regarding the publication of this paper.

\section{References}

1. Ahmed AI, Bissett SL, Beddows S. Amino acid sequence diversity of the major human papillomavirus capsid protein: implications for current and next generation vaccines. Infect Genet Evol. 2013;18:151-9. doi: 10.1016/j.meegid.2013.05.013. [PubMed: 23722024].

2. Ashrafi GH, Haghshenas M, Marchetti B, Campo MS. E5 protein of human papillomavirus 16 downregulates HLA class I and interacts with the heavy chain via its first hydrophobic domain. Int J Cancer. 2006;119(9):2105-12. doi: 10.1002/ijc.22089. [PubMed: 16823848].

3. Hoque ME. Factors influencing the recommendation of the Human Papillomavirus vaccine by South African doctors working in a tertiary hospital. Afr Health Sci. 2016;16(2):567-75. doi: 10.4314/ahs.v16i2.26. [PubMed: 27605973].

4. Li N, Franceschi S, Howell-Jones R, Snijders PJ, Clifford GM. Human papillomavirus type distribution in 30,848 invasive cervical cancers worldwide: Variation by geographical region, histological type and year of publication. Int J Cancer. 2011;128(4):927-35. doi: 10.1002/ijc.25396. [PubMed: 20473886].

5. Pinto LA, Viscidi R, Harro CD, Kemp TJ, Garcia-Pineres AJ, Trivett M, et al. Cellular immune responses to HPV-18, -31, and -53 in healthy volunteers immunized with recombinant HPV-16 L1 virus-like particles. Virology. 2006;353(2):451-62. doi: 10.1016/j.virol.2006.06.021. [PubMed: 16863657].

6. Nosrati A, Naghshvar F, Torabizadeh Z, Haghshenas M, Sangsefidi H. Relationship between Human Papilloma Virus and Colorectal Cancer in Northern Iran. Middle East J Cancer. 2015;6(4):237-41.

7. Haghshenas MR, Mousavi T, Moosazadeh M, Afshari M. Human papillomavirus and breast cancer in Iran: a meta- analysis. Iran J Basic Med Sci. 2016;19(3):231-7. [PubMed: 27114791].

8. Fakhraei F, Haghshenas MR, Hosseini V, Rafiei A, Naghshvar F, Alizadeh-Navaei R. Detection of human papillomavirus DNA in gastric carcinoma specimens in a high-risk region of Iran. Biomed Rep. 2016;5(3):371-5. doi: 10.3892/br.2016.728. [PubMed: 27588180].

9. Malary M, Moosazadeh M, HamzehgardeshiZ, Afshari M, Moghaddasifar I, Afsharimoghaddam A. The Prevalence of Cervical Human Papillomavirus Infection and the Most At-risk Genotypes Among Iranian Healthy Women: A Systematic Review and Meta-analysis. Int J Prev Med. 2016;7:70. doi: 10.4103/2008-7802.181756. [PubMed: 27217936].

10. Haghshenas MR, Marchetti B, Campo MS, Ashrafi GH. Human papillomavirus type 16 (HPV-16) E5 protein and HLA class I. Iran JPublic Health. 2005;34(Sup):48-9.

11. Hampras SS, Rollison DE, Tommasino M, Gheit T, Schabath MB, Messina JL, et al. Genetic variations in the epidermodysplasia verruciformis (EVER/TMC) genes, cutaneous human papillomavirus infection and squamous cell carcinoma of the skin. Br J Dermatol. 2015;173(6):1532-5. doi: 10.111/bjd.13991. [PubMed: 26126409].

12. de Koning MN, Quint KD, Bruggink SC, Gussekloo J, Bouwes Bavinck JN, Feltkamp MC, et al. High prevalence of cutaneous warts in elementary school children and the ubiquitous presence of wartassociated human papillomavirus on clinically normal skin. BrJ Dermatol. 2015;172(1):196-201. doi: 10.111//bjd.13216. [PubMed: 24976535].
13. Wilkinson EJ, Cox JT, Selim MA, O'Connor DM. Evolution of terminology for human-papillomavirus-infection-related vulvar squamous intraepithelial lesions. J Low Genit Tract Dis. 2015;19(1):81-7. doi: 10.1097/LGT.0000000000000049. [PubMed: 24832173].

14. Alemany L, Saunier M, Alvarado-Cabrero I, Quiros B, Salmeron J, Shin HR, et al. Human papillomavirus DNA prevalence and type distribution in anal carcinomas worldwide. Int J Cancer. 2015;136(1):98-107. doi: 10.1002/ijc.28963. [PubMed: 24817381].

15. De Vivar AD, Dawlett M, Wang JP, Jack A, Gong Y, Staerkel G, et al. Clinical performance of hybrid capture 2 human papillomavirus testing for recurrent high-grade cervical/vaginal intraepithelial neoplasm in patients with an ASC-US Papanicolaou test result during long-term posttherapy follow-up monitoring. Arch Pathol Lab Med. 2015;139(2):219-24. doi: 10.5858/arpa.2013-0291-OA. [PubMed: 25611104].

16. Valentino K, Poronsky CB. Human Papillomavirus Infection and Vaccination. J Pediatr Nurs. 2016;31(2):e155-66. doi: 10.1016/j.pedn.2015.10.005. [PubMed: 26586310].

17. Arbyn M, Castellsague X, de Sanjose S, Bruni L, Saraiya M, Bray F, et al. Worldwide burden of cervical cancer in 2008. Ann Oncol. 2011;22(12):2675-86. doi: 10.1093/annonc/mdr015. [PubMed: 21471563].

18. Fardows J, Nehar N, Laskar N, Joly SN. Human Papilloma Virus Vaccine: Future of Cervical Cancer Prevention. J Enam Med College. 2016;6(3):157-60.

19. Zhao W, Hao M, Wang Y, Feng N, Wang Z, Wang W, et al. Association between folate status and cervical intraepithelial neoplasia. Eur J Clin Nutr. 2016;70(7):837-42. doi: 10.1038/ejcn.2016.35. [PubMed: 27026426].

20. Haghshenas M, Golini-Moghaddam T, Rafiei A, Emadeian O, Shykhpour A, Ashrafi GH. Prevalence and type distribution of high-risk human papillomavirus in patients with cervical cancer: a populationbased study. Infect Agent Cancer. 2013;8(1):20. doi: 10.1186/1750-9378-820. [PubMed: 23738651].

21. Kang WD, Kim SM. Human papillomavirus genotyping as a reliable prognostic marker of recurrence after loop electrosurgical excision procedure for high-grade cervical intraepithelial neoplasia (CIN2-3) especially in postmenopausal women. Menopause. 2016;23(1):81-6. doi: 10.1097/GME.0000000000000488. [PubMed: 26057824].

22. Garcia-Hernandez E, Gonzalez-Sanchez JL, Andrade-Manzano A, Contreras ML, Padilla S, Guzman CC, et al. Regression of papilloma high-grade lesions (CIN 2 and CIN 3 ) is stimulated by therapeutic vaccination with MVA E2 recombinant vaccine. Cancer Gene Ther. 2006;13(6):592-7.

23. Brown DR, Kjaer SK, Sigurdsson K, Iversen OE, Hernandez-Avila M, Wheeler CM, et al. The impact of quadrivalent human papillomavirus (HPV; types 6, 11,16, and 18) L1 virus-like particle vaccine on infection and disease due to oncogenic nonvaccine HPV types in generally HPVnaive women aged 16-26 years. J Infect Dis. 2009;199(7):926-35.

24. Clifford GM, Smith JS, Plummer M, Munoz N, Franceschi S. Human papillomavirus types in invasive cervical cancer worldwide: a metaanalysis. BrJCancer. 2003;88(1):63-73.

25. Castellsague X. Natural history and epidemiology of HPV infection and cervical cancer. Gynecol Oncol. 2008;110(3):S4-7.

26. Jadad AR, Moore RA, Carroll D, Jenkinson C, Reynolds DJM, Gavaghan DJ. Assessing the quality of reports of randomized clinical trials: is blinding necessary?. Control Clin Trials. 1996;17(1):1-12.

27. Li Z, Geng YN, Jiang JD, Kong WJ. Antioxidant and anti-inflammatory activities of berberine in the treatment of diabetes mellitus. Evid Based Complement Alternat Med. 2014;2014:289264. doi: 10.1155/2014/289264. [PubMed: 24669227].

28. Mao C, Koutsky LA, Ault KA, Wheeler CM, Brown DR, Wiley DJ, et al. Efficacy of human papillomavirus-16 vaccine to prevent cervical intraepithelial neoplasia: a randomized controlled trial. Obstetr Gynecol. 2006;107(1):18-27.

29. Schiffman M, Clifford G, Buonaguro FM. Classification of weakly carcinogenic human papillomavirus types: addressing the limits of 
epidemiology at the borderline. Infect Agent Cancer. 2009;4:8. doi: 10.1186/1750-9378-4-8. [PubMed: 19486508].

30. Baseman JG, Koutsky LA. The epidemiology of human papillomavirus infections. J Clin Virol. 2005;32 Suppl 1:S16-24. doi: 10.1016/j.jcv.2004.12.008. [PubMed:15753008].

31. Kirnbauer R, Booy F, Cheng N, Lowy DR, Schiller JT. Papillomavirus L1 major capsid protein self-assembles into virus-like particles that are highly immunogenic. Proc Natl Acad Sci U S A. 1992;89(24):12180-4. [PubMed: 1334560].

32. Roden RB, Hubbert NL, Kirnbauer R, Christensen ND, Lowy DR, Schiller JT. Assessment of the serological relatedness of genital human papillomaviruses by hemagglutination inhibition. J Virol. 1996;70(5):3298-301. [PubMed: 8627814].

33. Brown DR, Kjaer SK, Sigurdsson K, Iversen OE, Hernandez-Avila M, Wheeler CM, et al. The impact of quadrivalent human papillomavirus (HPV; types 6, 11, 16, and 18) L1 virus-like particle vaccine on infection and disease due to oncogenic nonvaccine HPV types in generally HPVnaive women aged 16-26 years. J Infect Dis. 2009;199(7):926-35. doi: 10.1086/597307. [PubMed:19236279].

34. Suzich JA, Ghim SJ, Palmer-Hill FJ, White WI, Tamura JK, Bell JA, et al. Systemic immunization with papillomavirus L1 protein completely prevents the development of viral mucosal papillomas. Proc Natl Acad Sci U S A. 1995;92(25):11553-7. [PubMed: 8524802].

35. Breitburd F, Kirnbauer R, Hubbert NL, Nonnenmacher B, Trin-DinhDesmarquet $\mathrm{C}$, Orth $\mathrm{G}$, et al. Immunization with viruslike particles from cottontail rabbit papillomavirus (CRPV) can protect against experimental CRPV infection. J Virol. 1995;69(6):3959-63. [PubMed: 7745754].

36. Kirnbauer R, Chandrachud LM, O’Neil BW, Wagner ER, Grindlay GJ, Armstrong A, et al. Virus-like particles of bovine papillomavirus type 4 in prophylactic and therapeutic immunization. Virology. 1996;219(1):37-44. doi: 10.1006/viro.1996.0220. [PubMed: 8623552].

37. Christensen ND, Reed CA, Cladel NM, Han R, Kreider JW. Immunization with viruslike particles induces long-term protection of rabbits against challenge with cottontail rabbit papillomavirus. J Virol. 1996;70(2):960-5. [PubMed: 8551636].

38. Roden RBS, Yutzy WH, Fallon R, Inglis S, Lowy DR, Schiller JT. Minor capsid protein of human genital papillomaviruses contains subdominant, cross-neutralizing epitopes. Virology. 2000;270(2):254-7.

39. Gambhira R, Jagu S, Karanam B, Gravitt PE, Culp TD, Christensen $\mathrm{ND}$, et al. Protection of rabbits against challenge with rabbit papillomaviruses by immunization with the $\mathrm{N}$ terminus of human papillomavirus type 16 minor capsid antigen L2.J Virol. 2007;81(21):11585-92. doi: 10.1128/JVI.01577-07. [PubMed: 17715230].

40. Gambhira R, Karanam B, Jagu S, Roberts JN, Buck CB, Bossis I, et al. A protective and broadly cross-neutralizing epitope of human papillomavirus L2. J Virol. 2007;81(24):13927-31. doi: 10.1128/JVI.00936-07. [PubMed: 17928339].

41. Miura S, Matsumoto K, Oki A, Satoh T, Tsunoda H, Yasugi T, et al. Do we need a different strategy for HPV screening and vaccination in East Asia?. Int J Cancer. 2006;119(11):2713-5. doi: 10.1002/ijc.22195. [PubMed: 16929495].

42. Onuki M, Matsumoto K, Satoh T, Oki A, Okada S, Minaguchi T, et al. Human papillomavirus infections among Japanese women: agerelated prevalence and type-specific risk for cervical cancer. Cancer Sci. 2009;100(7):1312-6. doi: 10.1111/j.1349-7006.2009.01161.x. [PubMed: 19432906].

43. Villa LL, Costa RL, Petta CA, Andrade RP, Ault KA, Giuliano AR, et al. Prophylactic quadrivalent human papillomavirus (types $6,11,16$, and 18) L1 virus-like particle vaccine in young women: a randomised doubleblind placebo-controlled multicentre phase II efficacy trial. Lancet Oncol. 2005;6(5):271-8. doi: 10.1016/S1470-2045(05)70101-7. [PubMed: 15863374].

44. Olsson SE, Villa LL, Costa RL, Petta CA, Andrade RP, Malm C, et al. Induction of immune memory following administration of a prophylactic quadrivalent human papillomavirus (HPV) types 6/11/16/18
L1 virus-like particle (VLP) vaccine. Vaccine. 2007;25(26):4931-9. doi 10.1016/j.vaccine.2007.03.049. [PubMed: 17499406].

45. Villa LL, Costa RL, Petta CA, Andrade RP, Paavonen J, Iversen OE, et al. High sustained efficacy of a prophylactic quadrivalent human papillomavirus types 6/11/16/18 L1 virus-like particle vaccine through 5 years of follow-up. Br J Cancer. 2006;95(11):1459-66. doi: 10.1038/sj.bjc.6603469. [PubMed: 17117182].

46. Winer RL, Lee SK, Hughes JP, Adam DE, Kiviat NB, Koutsky LA. Genital human papillomavirus infection: incidence and risk factors in a cohort of female university students. Am JEpidemiol. 2003;157(3):218-26. [PubMed: 12543621].

47. Harper DM, Franco EL, Wheeler CM, Moscicki AB, Romanowski B, Roteli-Martins CM, et al. Sustained efficacy up to 4.5 years of a bivalent L1 virus-like particle vaccine against human papillomavirus types 16 and 18: follow-up from a randomised control trial. Lancet. 2006;367(9518):1247-55. doi: 10.1016/S0140-6736(06)68439-0. [PubMed: 16631880].

48. Block SL, Nolan T, Sattler C, Barr E, Giacoletti KE, Marchant CD, et al. Comparison of the immunogenicity and reactogenicity of a prophylactic quadrivalent human papillomavirus (types $6,11,16$, and 18) L1 virus-like particle vaccine in male and female adolescents and young adult women. Pediatrics. 2006;118(5):2135-45. doi: 10.1542/peds.20060461. [PubMed: 17079588].

49. Maw RD, Reitano M, Roy M. An international survey of patients with genital warts: perceptions regarding treatment and impact on lifestyle. Int J STD AIDS. 1998;9(10):571-8. [PubMed: 9819106].

50. Johnson AM, Mercer $\mathrm{CH}$, Erens B, Copas AJ, McManus S, Wellings K, et al. Sexual behaviour in Britain: partnerships, practices, and HIV risk behaviours. Lancet. 2001;358(9296):1835-42. doi: 10.1016/S01406736(01)06883-0. [PubMed: 11741621].

51. Wellings K, Nanchahal K, Macdowall W, McManus S, Erens B, Mercer $\mathrm{CH}$, et al. Sexual behaviour in Britain: early heterosexual experience. Lancet. 2001;358(9296):1843-50. doi: 10.1016/S0140-6736(01)06885-4. [PubMed: 11741623].

52. Grunbaum JA, Kann L, Kinchen S, Ross J, Hawkins J, Lowry R, et al. Youth risk behavior surveillance-United States, 2003. MMWR Surveill Summ. 2004;53(2):1-96. [PubMed: 15152182].

53. Perez G, Lazcano-Ponce E, Hernandez-Avila M, Garcia PJ, Munoz N Villa LL, et al. Safety, immunogenicity, and efficacy of quadrivalent human papillomavirus (types 6, 11, 16, 18) L1 virus-like-particle vaccine in Latin American women. Int J Cancer. 2008;122(6):1311-8. doi: 10.1002/ijc.23260. [PubMed: 18000825].

54. Yoshikawa H, Ebihara K, Tanaka Y, Noda K. Efficacy of quadrivalent human papillomavirus (types $6,11,16$ and 18 ) vaccine (GARDASIL) in Japanese women aged 18-26 years. Cancer Sci. 2013;104(4):465-72. doi: 10.1111/cas.12106. [PubMed: 23331518].

55. Harper DM, Franco EL, Wheeler C, Ferris DG, Jenkins D, Schuind A, et al Efficacy of a bivalent L1 virus-like particle vaccine in prevention of infection with human papillomavirus types 16 and 18 in young women: a randomised controlled trial. Lancet. 2004;364(9447):1757-65. doi: 10.1016/S0140-6736(04)17398-4. [PubMed: 15541448].

56. Gravitt PE, Shah KV. A Virus-based Vaccine May Prevent Cervical Cancer. Curr Infect Dis Rep. 2005;7(2):125-31. [PubMed: 15727740].

57. Markowitz LE, Dunne EF, Saraiya M, Chesson HW, Curtis CR, Gee J, et al. Human papillomavirus vaccination: recommendations of the Advisory Committee on Immunization Practices (ACIP). MMWR Recomm Rep. 2014;63(RR-05):1-30. [PubMed: 25167164].

58. Paavonen J, Jenkins D, Bosch FX, Naud P, Salmeron J, Wheeler CM et al. Efficacy of a prophylactic adjuvanted bivalent L1 virus-likeparticle vaccine against infection with human papillomavirus types 16 and 18 in young women: an interim analysis of a phase III doubleblind, randomised controlled trial. Lancet. 2007;369(9580):2161-70. doi: 10.1016/S0140-6736(07)60946-5. [PubMed: 17602732].

59. Koutsky LA, Ault KA, Wheeler CM, Brown DR, Barr E, Alvarez FB, et al A controlled trial of a human papillomavirus type 16 vaccine. $N$ Engl 
